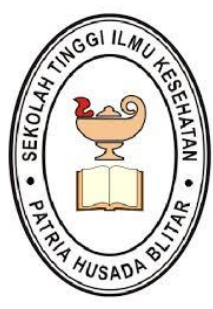

JNK

JURNAL NERS DAN KEBIDANAN

(JOURNALOFNERS AND MIIDWIFERY)

http://jnk.phb.ac.id/index.php/jnk

\title{
Butterfly Hug to Reduce Anxiety on Elderly
}

Pria Wahyu Romadhon Girianto ${ }^{1}$, Dhina Widayati ${ }^{2}$, Syahdila Sabrina Agusti ${ }^{3}$

CrossMark

${ }^{123}$ Bachelor Nursing Program, Karya Husada Institute of Health Science, Indonesia

\begin{tabular}{ll}
\hline Article Information & Abstract \\
\hline History Article: & $\begin{array}{l}\text { The problem that often occurs in the elderly is anxiety. Anxiety can lead to } \\
\text { Received, 05/09/2021 }\end{array}$ \\
Accepted, 19/10/2021 & $\begin{array}{l}\text { terfly Hug is a non-pharmacological therapy to reduce anxiety levels. This } \\
\text { research aims to determine the effectiveness of the butterfly hug on the level } \\
\text { of anxiety in the elderly. The research design was a pre-experimental design }\end{array}$ \\
Keywords: & with a one-group pre and post test design approach. The research popula- \\
Butterfly Hug, Elderly, Anxiety Level & tion was 60 people and a sample of 18 respondents was taken by purposive \\
& sampling technique. Anxiety level instrument using the GAI questionnaire. \\
& $\begin{array}{l}\text { Data analysis was used the Wilcoxon test. The results of the pre-test showed } \\
\text { that half of the respondents (50.0\%) experienced severe anxiety, half of the } \\
\text { respondents (50.0\%) experienced moderate anxiety. The post-test results } \\
\text { showed that half of the respondents (50.0\%) experienced moderate anxiety } \\
\text { and half of the respondents (50.0\%) experienced mild anxiety. p-value } 0.003\end{array}$ \\
& $\begin{array}{l}\text { and } 0.05 \text { (0.003 0.05) meaning that there is an influence of the Butterfly Hug } \\
\text { on the level of anxiety in the elderly. The Butterfly Hug is done by gently } \\
\text { clapping hands, which gives a comfortable sensation while breathing. This } \\
\text { method can activate LHPA, stimulate the hypothalamus and CRH hormone } \\
\text { secretion. ACTH is activated and stimulates the production of serotonin and } \\
\text { endorphin hormones which make you feel relaxed and safe, so that anxiety } \\
\text { decreases. It is recommended to use the Butterfly Hug as an alternative to } \\
\text { reduce the level of anxiety in the elderly at UPT PSTW Jombang-Kediri. }\end{array}$
\end{tabular}

(C) 2021 Journal of Ners and Midwifery

Correspondence Address:

Karya Husada Institute of Health Science - East Java, Indonesia

P-ISSN : 2355-052X

Email: priawahyu88@gmail.com

E-ISSN : $2548-3811$

DOI: 10.26699/jnk.v8i3.ART.p295-300

This is an Open Access article under the CC BY-SA license (http://creativecommons.org/licenses/by-sa/4.0/) 


\section{INTRODUCTION}

The elderly are a group of people aged 60 years and over [1]. Aging is a process that starts at birth and is commonly experienced by all living things. Aging can be seen from three perspectives, namely biological age, psychological age, and social age. Everyone will experience the process of aging and old age is the last period of human life.

Anxiety is one of mental disorder which commonly found among elderly. Anxiety disorder in elderly were triggered by various condition such as try to accept their situation and feel resigned, biological degeneration accompanied by various sufferings, such as several diseases, and the realization that everyone will die, so anxiety becomes an important psychological problem for the elderly.

Anxiety is a state of personality feeling, uncertainty, fear of reality or the perception of threats from actual sources that are not known or known. Anxiety is characterized by physical symptoms, including: cold fingers, faster heart rate, cold sweats, headache, decreased appetite, sleeplessness, and chest tightness. Symptoms of a mental nature are fear of feeling threatened by danger, unable to focus, uneasy, wanting to run away from reality. Factors that influence anxiety are frustration, conflict, threat, environment in the form of social support, education, age, and gender [2]. Several factors affect anxiety in the elderly, such as loneliness and other factors. Anxiety problems that often occur in the elderly are worries. Anxiety can lead to cognitive impairment, mood disorders, and other emotional disabilities [3].

Data from the United States Census Bureau estimates that Indonesia will experience the largest increase in elderly people worldwide in 1990-2025, which is $414 \%$. Data from the United States Population Service, the number of the elderly population aged 60 years is estimated at almost 600 million people and is predicted to be 2 billion in 2050. Currently, in Indonesia, there are 23.9 million people classified as elderly. From data obtained by the Ministry of Social Affairs, 3 million (2.9 million to be exact) of them are displaced. Indonesia is the fifth country that has the largest elderly population in the world. In 1990, the number of elderly people was around 12.7 million (6.29 percent) and in 2000 it reached 14.4 million (7.18 percent). In 2020, it is estimated to be 28.8 million people, or 11.34 percent of the total population of Indonesia [4].
East Java, as one of the provinces in Indonesia, has the third highest percentage of elderly people after Central Java and Yogyakarta Special Region [5]. The percentage of the elderly in East Java reached $12.253 \%$ of the total population. So every year, the elderly in Indonesia experience a significant increase.

The increasing number of elderly people requires serious treatment because, naturally, the elderly experience a decline both in terms of physical, biological, and mental health, and this can not be separated from economic, social, and cultural problems, so there is a need for family participation and a social role in handling it. The decline in the function of various organs of the elderly makes them vulnerable to diseases that are acute or chronic. There is a tendency for degenerative diseases, metabolic diseases, psychosocial disorders, and infectious diseases to increase.

Other problems that often occur in the elderly are loss, poverty, not being accepted/rejected, not yet finding the meaning of life, feeling dependent, helpless, and giving up easily, fear of death, sadness because of the death of others, physical and mental decline, depression, and feelings of sadness [6]. Loneliness is a condition that often threatens the lives of the elderly when family members live apart from them, lose a life partner, lose friends, and are powerless to live independently.

It is estimated that $15 \%$ to $20 \%$ of people over the age of 65 have mental disorders. Mental disorders that are often found in the elderly are insomnia, stress, depression, anxiety, dementia, and delirium or psychiatry. Research conducted by Eric J. Lenze, MD, at the University of Pittsburgh School of Medicine, shows that anxiety disorders are more common in older people, with $7 \%$ of anxiety occurring in older people. In addition, a research published in the American Journal of Psychiatry found that $10 \%$ of adults aged $55-85$ years experience anxiety [7].

In the results of Heningsih's research, regarding the description of the level of anxiety in 52 elderly people at Panti Werdha Darma Bakti Kasih Surakarta, it was found that $15 \%$ did not experience anxiety, $36.5 \%$ mild anxiety, $42.3 \%$ moderate anxiety, and $5.8 \%$ severe anxiety [8]. Based on data obtained by researchers at the Tresna Werdha Jombang Social Service, Kediri, the officer explained that $60.2 \%$ of the 60 elderly living in the Tresna Werdha Social Service experienced signs of anxi- 
ety such as restlessness, worry, irritability and confusion. This is due to economic problems, leaving their spouse/family, having biological children and siblings, but they don't have much time because they are busy working all day. So far, the routine activities at UPT PSTW Jombang-Kediri are praying and there is no special intervention for the elderly who experience anxiety.

The Butterfly Hug is an alternative solution to overcome anxiety in lonely elderly people, it carried out is by crossing both hands on the chest and then clapping both hands like the flapping wings of a butterfly. Do it while inhaling slowly and exhaling slowly. The butterfly hug is a method of direct bilateral stimulation (such as eye movement or pressure) to reduce anxiety and calm oneself. This method was developed by therapists Lucina Artigas and Ignacio Jarero during their work with survivors of Hurricane Pauline [7].

Generally, people with trauma disorders can experience symptoms again if they remember or experience things that triggered anxiety. To manage these triggers can be done by trying to calm yourself and your mind. The response of the autonomic nervous system to fear and anxiety causes involuntary activities in the body which are included in the self-defense mechanism. Physiologically, stressful situations activate the hypothalamus, which in turn activates two main stress pathways, namely the endocrine system (adrenal cortex) and the autonomic nervous system (sympathetic and parasympathetic).

To activate the endocrine system, after the hypothalamus receives a stress or anxiety stimulus, the anterior part of the hypothalamus releases Corticotropin Releasing Hormone (CRH), which instructs the anterior pituitary gland to secrete Adrenocorticotropin Hormone (ACTH). With the secretion of the hormone ACTH into the blood, this hormone activates the zona fasciculata of the adrenal cortex to secrete the glucorticoid hormone, namely cortisol. This hormone, cortisol, also plays a role in the negative feedback process that is delivered to the hypothalamus and then the signal is transmitted to the amygdala to strengthen the effect of stress on one's emotions.

In addition, this negative feedback will stimulate the anterior hypothalamus to release thyrotropic releasing hormone (TRH) and will instruct the anterior pituitary gland to release thyrotropic hormone (TTH). This TTH will stimulate the thyroid gland to secrete the hormone thyroxine, which causes changes in blood pressure, pulse rate, increased free fatty acids, and also increased anxiety.

The Butterfly Hug method was used by many psychiatrists to reduce anxiety, especially for trauma patients. In addition to trauma, anxiety is often experienced by lonely elderly people. Because lonely elderly people will usually experience anxiety due to being left by their family and others. So the elderly need action to overcome the anxiety they experience. And the Butterfly Hug method is an alternative solution to calm the mind by using suggestions that can provide comfort and tranquility for the elderly. This method can be used easily and can be done at anytime by the elderly.

\section{METHOD}

The research design was used a pre-experimental design with a one-group pre and post test design approach. Research was done at UPT PSTW Jombang-Kediri for 1 week. The sampling technique was used "purposive sampling" or saturated sampling, which was adjusted to the research objectives and selected based on inclusion criteria, namely the elderly who experienced anxiety, the elderly who were willing to participate in the research, the elderly who were not physically disabled, the femae elderly, and the elderly who are 60 years old and over. The sample who met the inclusion criteria, as many as 18 elderly.

Before treatment, the researcher introduced themselves to respondent in order to build trust and created therapeutic environment. Geriatric Anxiety Inventory (GAI) were distributed to respondents to measure anxiety level before intervention. Butterfly Hug was conducted every 1 week meeting, were held 3 times, and every 1 meeting lasted 30 minutes/until calm. The last stage, researcher evaluating the level of anxiety in the elderly, to know if the level of anxiety decreases or increases after Butterfly Hug therapy.

\section{RESULT}

The presentation of respondents characteristic data includes age, education history, employment status, marital status, and daily activities.

Based on Table 1, it could be conclude that the age distribution of most respondents $(61.1 \%)$ aged 66-70 years. Distribution of the last education, all 
Table 1 Respondents Characteristic

\begin{tabular}{lcc}
\hline Variable & $\boldsymbol{f}$ & $\%$ \\
\hline Age & & \\
$\quad$ 60-65 years old & 7 & 38,9 \\
$\quad$ 66-70 years old & 11 & 61,1 \\
\hline Education & & \\
$\quad$ Elementary School & 18 & 100,0 \\
\hline Employment & & \\
$\quad$ Unemployment & 18 & 100,0 \\
\hline Marital State & & \\
$\quad$ Married & 3 & 17,7 \\
$\quad$ Widow & 15 & 83,3 \\
\hline Daily Activity & & \\
$\quad$ Stay at Room & 12 & 66,7 \\
$\quad$ Chat with others & 2 & 11,1 \\
$\quad$ Make Crafts & 4 & 22,2 \\
\hline
\end{tabular}

$(100 \%)$ were at the elementary school level. The distribution of work entirely $(100 \%)$ was not working. The distribution of marital status was almost entirely $(83.3 \%)$ widows. The distribution of daily activities mostly (66.7\%) sat or stayed in the room.

Tabel 2 Pretest Anxiety Level Data

\begin{tabular}{lcc}
\hline Category & f & \% \\
\hline No Anxiety & 0 & 0 \\
Mild Anxiety & 0 & 0 \\
Moderate Anxiety & 9 & 50,0 \\
Severe Anxiety & 9 & 50,0 \\
Panic & 0 & 0 \\
\hline Total & $\mathbf{1 8}$ & $\mathbf{1 0 0 , 0}$
\end{tabular}

Based on Table 2, it could be conclude that the respondents $(50.0 \%)$ have a moderate level of anxiety. And half of the respondents $(50.0 \%)$ have a severe level of anxiety.

Based on Table 3, it could be conclude that the respondents $(50.0 \%)$ have a moderate level of anxiety. And half of the respondents $(50.0 \%)$ had a mild level of anxiety.

Based on Table 4, the average pretest was 10.22, while the posttest showed an average of 15.11. The Wilcoxon test result obtained $\mathrm{p}$-value $0.003(0.05)$ then hypothesis was accepted, so it could be concluded that there was an effect of the
Tabel 3 Posttest Anxiety Level Data

\begin{tabular}{lcc}
\hline Category & f & \% \\
\hline No Anxiety & 0 & 0 \\
Mild Anxiety & 9 & 50,0 \\
Moderate Anxiety & 9 & 50,0 \\
Severe Anxiety & 0 & 0 \\
Panic & 0 & 0 \\
\hline Total & $\mathbf{1 8}$ & $\mathbf{1 0 0 , 0}$ \\
\hline
\end{tabular}

Tabel 4 Statistical Analysis

\begin{tabular}{|c|c|c|c|c|}
\hline \multirow{2}{*}{ Category } & \multicolumn{2}{|c|}{ Pre-Test } & \multicolumn{2}{|c|}{ Post-test } \\
\hline & $\mathbf{N}$ & $(\%)$ & $\mathbf{N}$ & $(\%)$ \\
\hline No Anxiety & 0 & 0 & 0 & 0 \\
\hline Mild Anxiety & 0 & 0 & 9 & 50,0 \\
\hline Moderate Anxiety & 9 & 50,0 & 9 & 50,0 \\
\hline Severe Anxiety & 9 & 50,0 & 0 & 0 \\
\hline Panik & 0 & 0 & 0 & 0 \\
\hline Total & 18 & \multicolumn{3}{|c|}{18} \\
\hline Mean & 10,22 & \multicolumn{3}{|c|}{15,11} \\
\hline Wilcoxon Test & & \multicolumn{3}{|c|}{ p-value $0.003<0.05$} \\
\hline
\end{tabular}

Butterfly Hug method on the level of anxiety in the elderly at UPT PSTW Jombang-Kediri.

\section{DISCUSSION}

After being given treatment in the form of the Butterfly Hug method for 1 week with 3 meetings, there was a change in the level of anxiety at UPT PSTW Jombang-Kediri. A change was found in all respondents. Changes in respondents were proven by the results of the GAI questionnaire scores, where the results obtained after being given the Butterfly Hug method showed half of the respondents $(50.0 \%)$ experienced moderate anxiety and half of the respondents $(50.0 \%)$ experienced mild anxiety. Differences in respondent characteristics also affect the decrease in anxiety levels. In respondent number 7 , there is an increase in GAI score by 12 points, while in respondent number 3 , there is only an increase in GAI score by 2 points. Respondent number 7 is more open to the problems experienced, while respondent number 3 is easier to feel annoyed with his friends. The decrease in anxiety in respondents makes respondents more able to adapt to the surrounding environment, 
actively participate in activities and more able to establish interpersonal relationships. This is in accordance with the results of Untari, I \& Rohmawati research that one of the causes of anxiety is one's work or activity. Too much or too little can cause anxiety [9].

Based on the results of data analysis using the Wilcoxon test, it is known that $\mathrm{p}$ value $=0.003$ and $\alpha=0.05$, so $p$ value $0.003<0.05$, which means that there is an effect of the Butterfly Hug method on anxiety levels in the elderly at UPT PSTW Jombang-Kediri. In accordance with the functional consequence theory by Miller, giving an intervention can change a negative functional consequence into a positive functional consequence [3]. In this research, giving an intervention in the form of the Butterfly Hug method changed the negative functional consequences of anxiety into positive functional consequences, namely a decrease in anxiety levels. This research is in line with previous research by Siti Aisyah. In this research, the results obtained a significant effect of the intervention of the Butterfly Hug method on stress levels, but the application of the Butterfly Hug method on anxiety still needs to be studied further [10].

The Butterfly Hug method has advantages in its application. The advantage is that it can be done at any time and place, allowing the elderly to reduce anxiety. As we know, the Butterfly Hug method is a type of bilateral stimulation, namely the use of external visual, auditory, or tactile stimuli sequentially to help clients process traumatic memories. According to the Association for Comprehensive Energy Psychology, this method can also make the heart feel spacious, balance the left and right brain, so that lonely seniors can resolve the intense emotions they are experiencing.

Most of the respondents admitted that they were comfortable when doing the Butterfly Hug method. Complaints of anxiety and worry that are felt slowly disappear. Other respondents showed optimistic thinking or did not tend to think about bad things that would happen in the future. This agrees with the research that the Butterfly Hug method provides benefits for the formation of a better mood, so that the elderly who regularly participate in activities will always feel comfortable. A comfortable feeling condition makes individuals able to optimize functioning mental processes and also affects the individual's ability to deal with any problems that could cause stress [10].
In addition, all respondents said they were happy to participate in activities because there were new activities that could provide a feeling of comfort and safety and create a sense of joy and togetherness among the elderly. Therefore, the Butterfly Hug method still plays a role in changing the level of anxiety in the elderly. Suardiman argues that when a person is in a state of anxiety and physiological tension, it activates the Limbic Hypothalamus Puitutory Adrenal Axis (LHPA), which stimulates the hypothalamus and causes the secretion of corticotrophin releasing hormone (CRH). This causes the activation of Adeno Cortico Trophin Hormone (ACTH) which stimulates the production of serotonin and endorphins hormones which will make individuals happy, happy, comfortable, sleep better, and keep the mind fresh. In addition to physical activity and exercise, psychological mechanisms will appear. and neurobiology so that antidepressant and anxiolytic effects can occur which can reduce anxiety levels [11].

\section{CONCLUSION}

There was an effect of the butterfly hug method on the level of anxiety in the elderly at UPT PSTW Jombang-Kediri.

\section{SUGGESTION}

Suggestion for further researchers, they can develop the same theme with a larger number of samples in order to get maximum results. In addition, it can add a control group as a comparison in the research, so that the research can be more perfect.

\section{REFERENCES}

Sunaryo. 2016. Faktor yang Mempengaruhi Tingkat Kecemasan pada Lanjut Usia (LANSIA) di RW 1, Kelurahan Ploso, Kecamatan Tambaksari, Kota Surabaya (Skripsi: Universitas Airlangga Surabaya)

Stuart \& Sundeen. 2016. Keperawatan Psikiatrik : Buku Saku Keperawatan Jiwa. Edisi 5. Jakarta:EGC

Miller, C.A. 2017. Nursing for Wellness in Older Adults. USA: Lippincot Williams \& Willkins

Jarero, I.,\& Artigas, L. 2017. The EMDR Integrative Group Treatment Protocol: Application with Adults During Ongoing Geopolitical Crisis. Journal of EMDR Practice and Research, 4(4), 148-155.

Kementrian Kesehatan RI. 2017. Pusat Data dan Informasi: Analisis Lansia di Indonesia. Jakarta Selatan 
Videbeck, Sheila L. 2016. Psychiatric Mental Health Nursing. Jakarta:EGC

Jarero, I. Artigas, L. \& Luber, M. 2018. The EMDR protocol for recent critical incidents: Application in a disaster mental health continuum of care context. Journal of EMDR Practice and Research, 5(3), 8294.

Heningsih. 2014. Gambaran Tingkat Ansietas pada Lansia di Panti Wredha Dharma Bhakti Kasih Surakarta (Skripsi : Sekolah Tinggi Ilmu Kesehatan Kusuma Husada)
Untari, I. \& Rohmawati, 2014. Faktor-faktor yang mempengaruhi kecemasan pada Usia Pertengahan dalam Menghadapi Proses Menua (Aging Process). Jurnal keperawatan AKPER 17 Karanganyar, 1.

Aisyah, Siti. 2017. Pengaruh Butterfly Hug Terhadap Penurunan Tingkat Kecemasan (Ansietas) pada Lansia di Panti Werdha Hargo Dedali Surabaya (Skripsi:Universitas Airlangga Surabaya)

Suardiman, S.2017. Psikologi Usia Lanjut. Yogyakarta: Gajah Mada University Press. 